Lecture Notes in Civil Engineering

Paulo A. G. Piloto

João Paulo Rodrigues

Valdir Pignatta Silva Editors
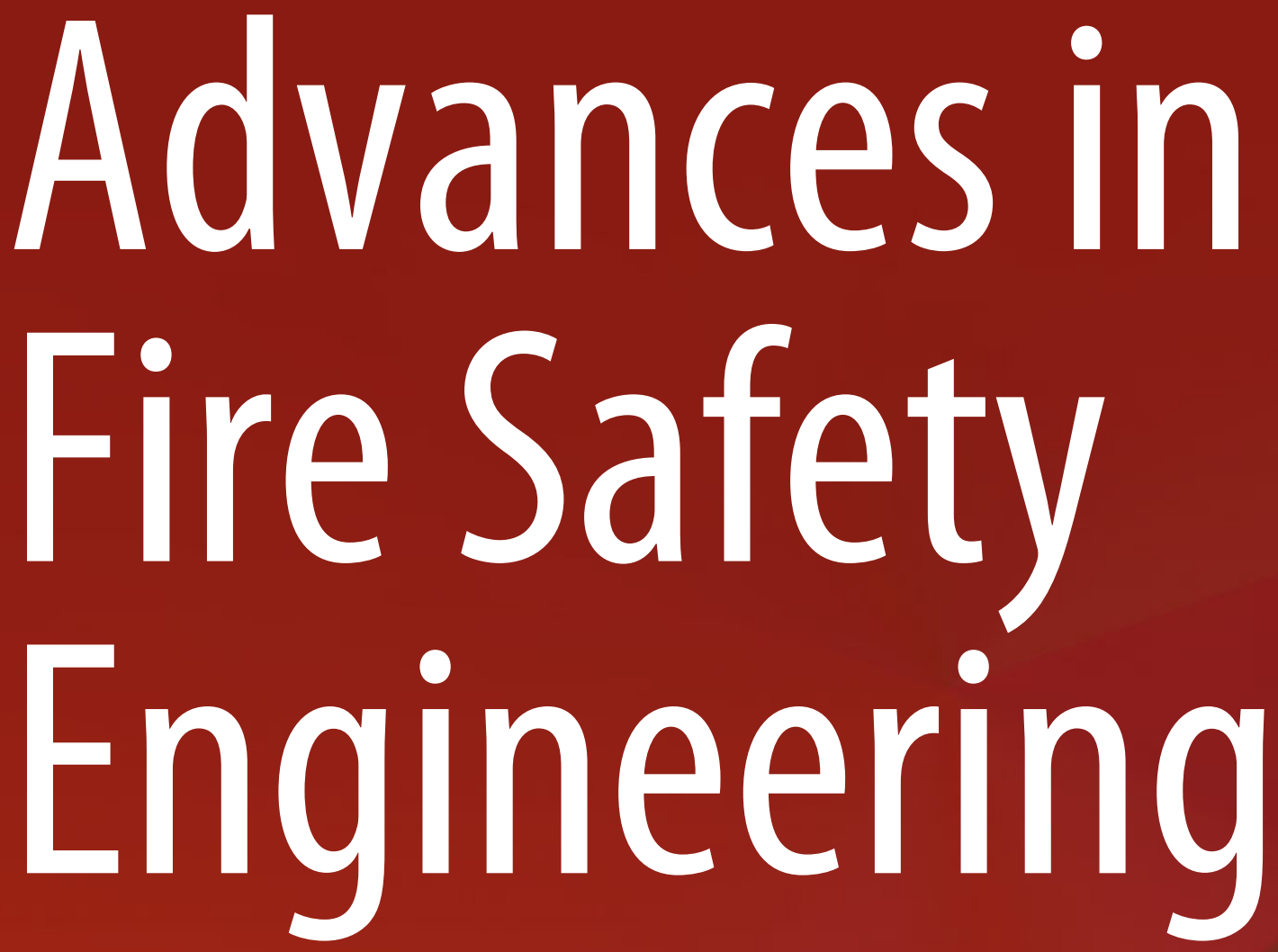

Selected Papers from the

5th Iberian-Latin-American Congress

on Fire Safety, CILASCI 5 ,

July 15-17, 2019, Porto, Portugal

Springer 


\section{Lecture Notes in Civil Engineering}

\section{Volume 1}

\section{Series Editors}

Marco di Prisco, Politecnico di Milano, Milano, Italy

Sheng-Hong Chen, School of Water Resources and Hydropower Engineering, Wuhan University, Wuhan, China

Ioannis Vayas, Institute of Steel Structures, National Technical University of Athens, Athens, Greece

Sanjay Kumar Shukla, School of Engineering, Edith Cowan University, Joondalup, WA, Australia

Anuj Sharma, Iowa State University, Ames, IA, USA

Nagesh Kumar, Department of Civil Engineering, Indian Institute of Science

Bangalore, Bangalore, Karnataka, India

Chien Ming Wang, School of Civil Engineering, The University of Queensland, Brisbane, QLD, Australia 
Lecture Notes in Civil Engineering (LNCE) publishes the latest developments in Civil Engineering - quickly, informally and in top quality. Though original research reported in proceedings and post-proceedings represents the core of LNCE, edited volumes of exceptionally high quality and interest may also be considered for publication. Volumes published in LNCE embrace all aspects and subfields of, as well as new challenges in, Civil Engineering. Topics in the series include:

- Construction and Structural Mechanics

- Building Materials

- Concrete, Steel and Timber Structures

- Geotechnical Engineering

- Earthquake Engineering

- Coastal Engineering

- Ocean and Offshore Engineering; Ships and Floating Structures

- Hydraulics, Hydrology and Water Resources Engineering

- Environmental Engineering and Sustainability

- Structural Health and Monitoring

- Surveying and Geographical Information Systems

- Indoor Environments

- Transportation and Traffic

- Risk Analysis

- Safety and Security

To submit a proposal or request further information, please contact the appropriate Springer Editor:

- Mr. Pierpaolo Riva at pierpaolo.riva@springer.com (Europe and Americas);

- Ms. Swati Meherishi at swati.meherishi@springer.com (Asia - except China and Australia/NZ);

- Ms. Li Shen at li.shen@springer.com (China).

\section{Indexed by Scopus}

More information about this series at http://www.springer.com/series/15087 
Paulo A. G. Piloto • João Paulo Rodrigues .

Valdir Pignatta Silva

Editors

\section{Advances in Fire Safety Engineering}

Selected Papers from the 5th

Iberian-Latin-American Congress on Fire

Safety, CILASCI 5, July 15-17, 2019,

Porto, Portugal

Springer 
Editors

Paulo A. G. Piloto

Instituto Politécnico de Bragança

Bragança, Portugal

Valdir Pignatta Silva

Universidade de São Paulo

São Paulo, Brazil
João Paulo Rodrigues

Universidade de Coimbra

Coimbra, Portugal

ISSN 2366-2557

ISSN 2366-2565 (electronic)

Lecture Notes in Civil Engineering

ISBN 978-3-030-36239-3

ISBN 978-3-030-36240-9 (eBook)

https://doi.org/10.1007/978-3-030-36240-9

(C) Springer Nature Switzerland AG 2020

This work is subject to copyright. All rights are reserved by the Publisher, whether the whole or part of the material is concerned, specifically the rights of translation, reprinting, reuse of illustrations, recitation, broadcasting, reproduction on microfilms or in any other physical way, and transmission or information storage and retrieval, electronic adaptation, computer software, or by similar or dissimilar methodology now known or hereafter developed.

The use of general descriptive names, registered names, trademarks, service marks, etc. in this publication does not imply, even in the absence of a specific statement, that such names are exempt from the relevant protective laws and regulations and therefore free for general use.

The publisher, the authors and the editors are safe to assume that the advice and information in this book are believed to be true and accurate at the date of publication. Neither the publisher nor the authors or the editors give a warranty, expressed or implied, with respect to the material contained herein or for any errors or omissions that may have been made. The publisher remains neutral with regard to jurisdictional claims in published maps and institutional affiliations.

This Springer imprint is published by the registered company Springer Nature Switzerland AG

The registered company address is: Gewerbestrasse 11, 6330 Cham, Switzerland 


\section{Preface}

This book gathers selected contributions presented during the 5th Iberian-Latin-American Congress on Fire Safety (CILASCI), held in Porto, Portugal, from 15-17 July 2019. The CILASCI is held once every two years, with the aim of disseminating scientific and technical knowledge in the field of fire safety, attracting different players involved in this area of knowledge.

The 5th Iberian-Latin-American Congress on Fire Safety reflected the new developments achieved in a wide range of application areas. The papers included in this book were selected out of 78 manuscripts (full papers), and five invited lectures, written and presented during six parallel sessions from researchers around the world (Algeria, Australia, Belgium, Brazil, China, Czech Republic, France, Hong Kong, Italy, Mozambique, Portugal, Spain, UK and USA).

The selected papers were peer-reviewed during and after the congress, and this selection process has resulted in new, extended, revised and full original versions covering the experimental analysis of materials and structures, the computational modelling of structures and materials, the fire events in special buildings and spaces, the architectural issues and evacuation topics for fire safety in buildings.

Fire safety has been advancing fast as a result of research, development and innovation worldwide; the new research programmes, the support of new skilled professionals and the existence of advanced training programmes in Fire Science Technology are not only expected to increase the safety level of people, buildings and products, but are also going to produce a positive impact in the economy of each country and society.

The editors gratefully acknowledge the members of the scientific committee and the experts who carried out the reviews of the manuscripts. They are also grateful to the organizing committee from the Polytechnic Institute of Bragança (IPB), the 
Faculty of Engineering of the University of Porto (FEUP) and the School of Engineering (ISEP) from the Polytechnic Institute of Porto, and the support from the Luso-Brazilian Association for Fire Safety (ALBASCI) is also acknowledged.

Paulo A. G. Piloto João Paulo Rodrigues Valdir Pignatta Silva 


\section{Contents}

Model Error for Calculating the Structural Reliability of Dowel Connections in Fire Situations . . . . . . . . . . . . . 1 Auro Cândido Marcolan Júnior and Poliana Dias de Moraes

Three-Dimensional Numerical Analysis on the Fire Behaviour of Composite Slabs with Steel Deck . . . . . . . . . . . . . . . 12 Paulo A. G. Piloto, Carlos Balsa, Fernando F. Ribeiro, and Ronaldo Rigobello

Durability of Reaction to Fire Performance of Wood Based Panels Through Accelerated Aging Cycles ................... 31

Luís Mesquita, Lucas Ferle, and Gerson Santos

Modelling Real Fire by FDS and 2-Zone Model for Structural

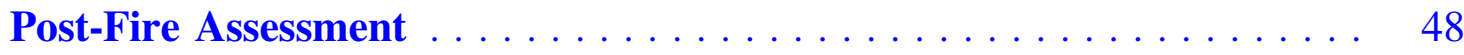

Tom Molkens and Barbara Rossi

Buckling Resistance of Partially Encased Columns Embedded on Walls Under Fire from One Side . . . . . . . . . . . . . 61

Paulo A. G. Piloto, Nathália Gonçales, Ronaldo Rigobello, Mário Vaz, Rui M. Guedes, and João S. Baptista

Numerical Analysis of Cellular Steel Beams Failure Modes

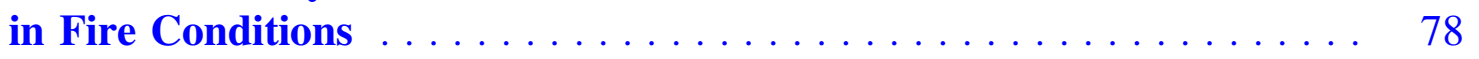

Jaqueline Silva, Paola Dalcanal, and Luís Mesquita

Wood Connections Under Fire Conditions Protected with Gypsum Plasterboard Types $\mathbf{A}$ and $\mathbf{F} \ldots \ldots \ldots \ldots \ldots \ldots \ldots \ldots . \ldots \ldots$

Elza M. M. Fonseca, Pedro A. S. Leite, and Lino Silva

Emergency Exits: Analysis and Reflection Based on a Modelling and Standardization Study .

Edna Moura Pinto and Mariana Lima Oliveira Montenegro 


\title{
Buckling Resistance of Partially Encased Columns Embedded on Walls Under Fire from One Side
}

\author{
Paulo A. G. Piloto ${ }^{1}\left(\mathbb{D}\right.$, Nathália Gonçales $^{2(\bowtie)}$, Ronaldo Rigobello ${ }^{2}$, \\ Mário Vaz ${ }^{3}$ (D), Rui M. Guedes ${ }^{3}$ (D), and João S. Baptista ${ }^{3}$ (D) \\ ${ }^{1}$ Instituto Politécnico de Bragança, Bragança 5300-253, Portugal \\ ${ }^{2}$ Universidade Tecnológica Federal do Paraná, Paraná 87301-899, Brazil \\ nathaliagoncales@alunos.utfpr.edu.br \\ ${ }^{3}$ Faculdade de Engenharia, Universidade do Porto, Porto 4200-465, Portugal
}

\begin{abstract}
Partially encased columns (PEC) have better fire resistance when compared to bare steel columns, due to the existence of concrete between the flanges. The aim of this study is to develop a new proposal for the calculation of the buckling strength of partially encased columns, embedded on walls, under fire conditions. This proposal is based on the current calculation method proposed in Annex G of EN 1994-1-2. This study uses the finite element method to calculate the average temperature of seven components. The average temperature is then used to find the buckling resistance of composite columns when submitted to fire from one side. This solution method is carried out using 30 different cross sections. All cross sections are exposed to the standard fire curve ISO834 from one side, assuming the specific fire rating of 30, 60, 90 and $120 \mathrm{~min}$.
\end{abstract}

Keywords: Partially encased columns $\cdot$ Fire resistance $\cdot$ Columns embedded on walls $\cdot$ Numerical simulation

\section{Introduction}

The steel columns have a great loadbearing capacity, however when exposed to fire conditions, they resist only to a relative short period of time. The partially encased composite columns consist in an excellent alternative solution to bare steel column. Partially Encased Columns (PEC) have higher strength and stiffness when compared to steel bare profiles under fire conditions. The fire resistance of the PEC depends on the temperature evolution in each material and component, being this temperature field affected by the protection effect of the wall.

The annex G of Eurocode EN 1994-1-2 [1], presents the balanced summation method, allowing the calculation of the buckling resistance of PEC, when submitted to standard fire conditions [2] from the 4 sides, but this annex does not take into consideration the embedded effect of this PEC in the wall. This method differs from the general calculation method and divides the cross section into four large components.

The non-symmetric temperature field over different types of materials and elements have been studied for long time. In 1988, Cooke [3] presented an experimental and 
theoretical study about the thermal bowing of building elements. The temperature field and gradient over the cross section depends on the material under analysis. Test data show that large thermal bowing deflections occur in unrestrained brick walls. The author also presented simple calculation models to deal with unrestrained thermal bowing effect on steel elements. The behaviour of composite elements is more complex due to the existence of non-linear thermal gradients in concrete. In 2007, Garlock and Quiel [4] presented the effect of thermal gradients in steel columns with wide flanges, which are responsible for modifying the position of the neutral axis to the coldest side, introducing extra bending moments. This shift effect also depends on the amount of axial load. In 2010, Correia et al. [5] presented a new proposal for the calculation method to evaluate the temperature of $\mathrm{H}$ steel columns embedded in single-leaf brick walls. This proposal was based on numerical simulations and fire resistance tests, taking into consideration two different relative positions between the steel profile and the brick wall. The proposal considered a temperature gradient, based on 3 isothermal zones or components (exposed, embedded and unexposed). In 2011, Dwaikat et al. [6] tested several wide-flanged steel beam-columns with induced temperature gradients. These temperature gradients were induced by the effect of the furnace into a partially protected column, considering the inexistence of fire protection materials in certain regions, allowing to define two main directions for the highest gradient (parallel and perpendicular to the web). This procedure simulated, according to authors, a realistic three-sided heating scenario. The column specimens developed bending moments in regards to these gradients. Major gradients were defined in the direction parallel to the web for both fire events. All columns failed by full section yielding. The plastic resistance due to the combinations of axial load and moment was affected by the thermal gradients. The experiments and computer models showed good agreement with the predicted demands and capacity. In 2014, Agarwal et al. [7] made an experimental and numerical investigation to analyse the behaviour of columns with thermal gradients in the cross section. The columns were submitted to uniform heating, that reached their failure temperatures faster than the columns subjected to non-uniform heating. The parametric analysis allowed the development of design equations for wide flanged steel columns subjected to non-uniform heating. In 2014, Quiel et al. [8] investigated three different models to predict the axial plastic load bearing capacity of steel columns with thermal gradients, using the code-based equations (American and European), using the fibre-beam element model and using the shell finite element model. Authors concluded that code-based equations are not satisfactory, since these equations do not consider temperature gradients. Both finite element models agree well with experimental results. The tests and models were very important to develop new simple formulae, which included de effect of moment reversal due to a shift in the section centre of stiffness, produced by the existence of temperature gradients. In 2014, Correia et al. [9] presented a numerical study that considered non-uniform temperature distribution in the cross section of restrained steel $\mathrm{H}$ columns embedded on walls, validated by experiments, proposing new interaction formulae for axial force and bending moment. The contact of the steel columns with the walls is responsible for a big reduction in the temperature of the cross-section, leading to higher fire resistance when compared to the ones observed in engulfed steel columns. According to the authors, these columns behave much more like beam-columns failing by bending, following the effect of the 
"thermal bowing", instead of failing by buckling. The application of the Eurocode 3 simple formula, considering a uniform temperature, within the cross-section, equal to the temperature of the exposed flange, would lead to a very conservative design. In 2016, Ojeda et al. [10] studied the effect of thermal gradients over the cross-section of steel columns by means of finite element simulations. Authors investigated the eccentricity in the column, created by the temperature gradient and the reduction of the flexural buckling resistance of the columns. Authors decided to simplify the calculation of the required parameters in order to handle a simple calculation method. A new design model was proposed, consisting of a set of simple equations which considers the eccentricity. The simplifications involve the calculation of the required material properties and geometric parameters at the average, maximum or minimum temperatures in the section. Rocha et al., in 2018 [11] studied the fire behaviour of steel columns and PEC embedded on masonry walls with restrained thermal elongation. Authors found that the magnitude of the thermal gradients and their directions have a strong effect on the mechanical behaviour and stability of the PEC under fire. The thickness of the wall influenced the bending stiffness of the tested columns, affecting the restraining forces and displacements. The thermal gradient in the cross section is responsible for the thermal bowing effect, introducing additional bending moments and axial forces.

This study presents an new approximation method to define the axial buckling resistance of Partially Encased Columns, embedded on walls, under fire, taking into consideration the temperature effect over the plastic resistance to axial compression $\mathrm{N}_{\mathrm{fi}, \mathrm{pl}, \mathrm{Rd}}$ and over the effective flexural stiffness $(\mathrm{EI})_{\mathrm{fi}, \mathrm{eff}, \mathrm{z}}$ around the minor axis.

\section{Partially Encased Columns Embedded on Walls}

This work investigates partially encased columns embedded on clay walls under standard fire from only one side (see Fig. 1) and proposes an alternative method to the balanced summation model, including the contribution of more components, due to the existence of asymmetric temperature field, with respect to the plane defined by the web of the PEC.

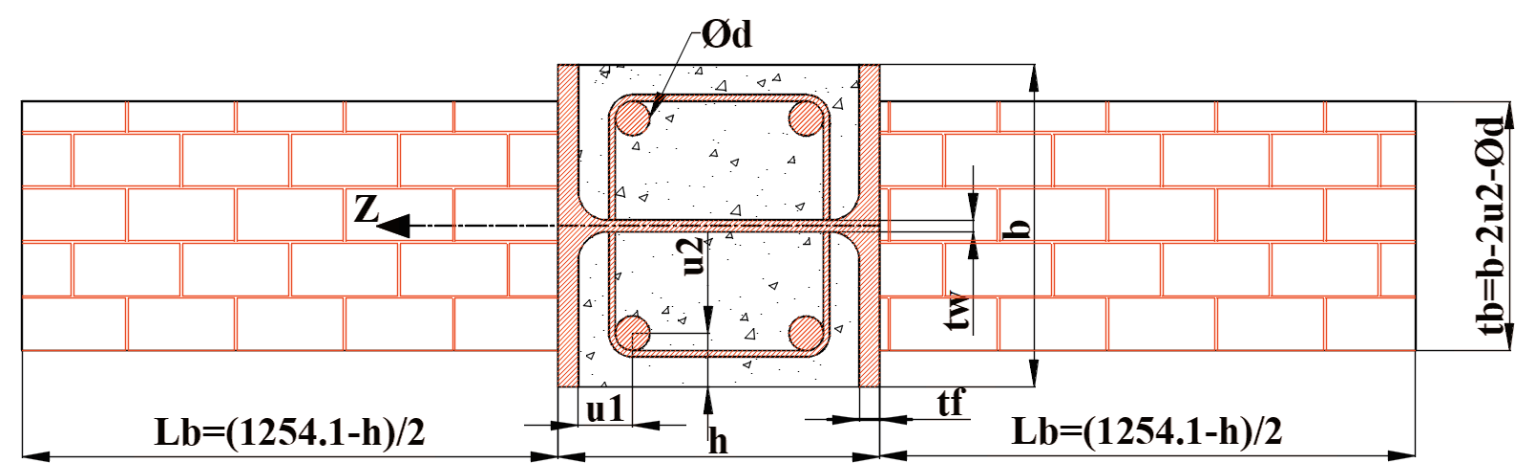

Fig. 1. Partially encased column embedded on wall. 
The thermal analysis of PEC deals with 30 different PEC, made by HEA, HD and UC cross section. The length and thickness of the wall changed, according to the values presented on Table 1.

Table 1. Section proprieties for the partially encased sections.

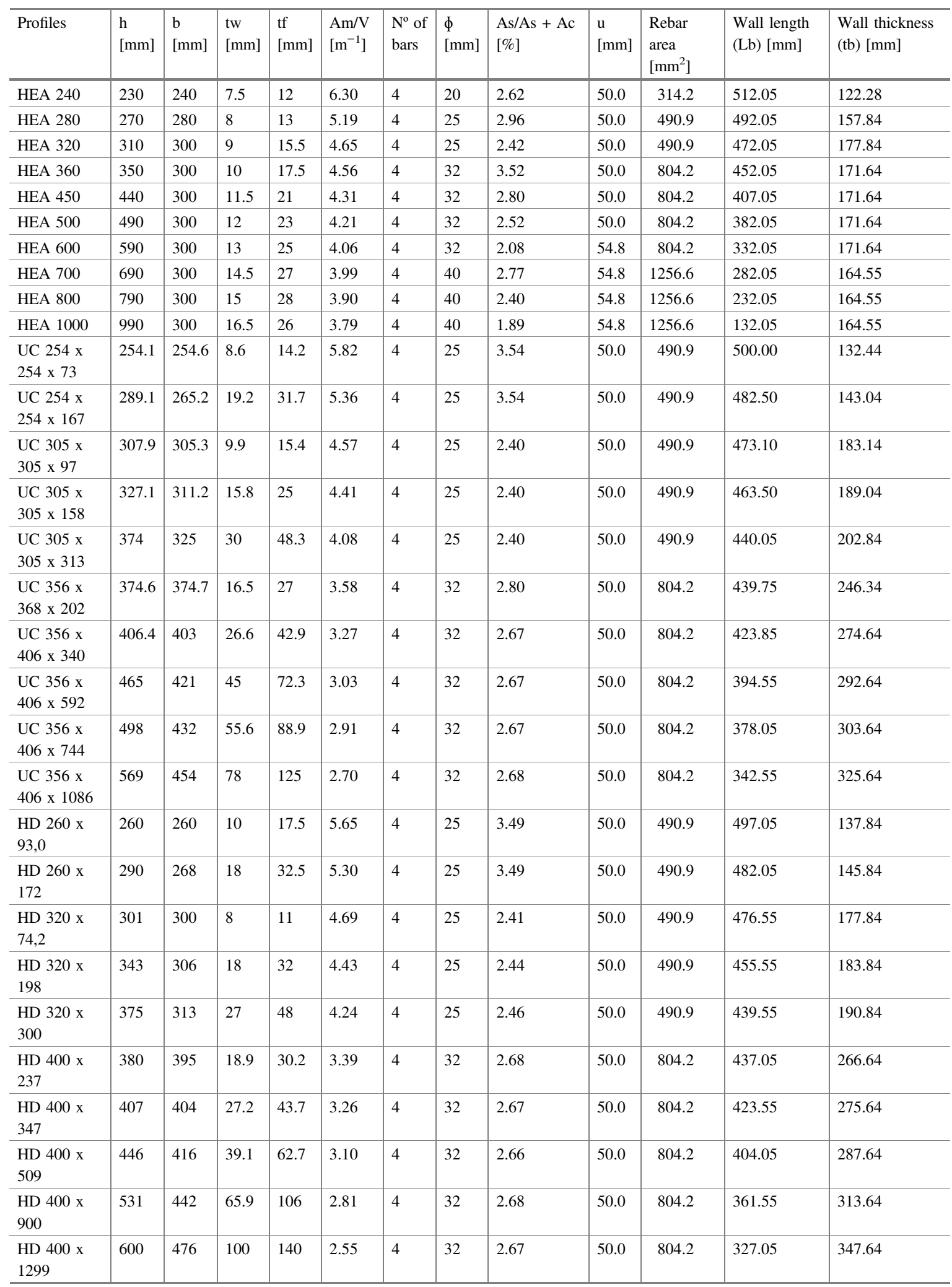


The grades of the materials are: S355 for the steel profiles, C20/25 for the encased concrete and B500 for rebars. A clay wall was considered on both sides of the partially encased section. The cross-section dimensions were selected to present a wide range of variation for the value of the section factor. The exposed perimeter and the total area of the cross section were used to calculate the section factor (see Eq. 1).

$$
\mathrm{A}_{\mathrm{m}} / \mathrm{V}=[(\mathrm{b}-\mathrm{tb})+\mathrm{h}] /(\mathrm{bh})
$$

The balanced summation model, presented in annex G [1], was originally developed to determine the loadbearing capacity of PEC under fire, dividing the cross section in four components, based on the assumption of doubly symmetric thermal behaviour and fire from 4 sides. In the following formulae, the four components of PEC are identified with, "f" for flanges, "w" for web, "c" for concrete and "s" for the reinforcing bars. The effect of each component on the plastic resistance to axial compression can be calculated using Eq. 2 (normal summation) and the effect on the effective flexural stiffness determined by Eq. 3 (balanced summation with reduction coefficients).

$$
\begin{gathered}
\mathrm{N}_{\mathrm{fi}, \mathrm{pl}, \mathrm{Rd}}=\mathrm{N}_{\mathrm{fi}, \mathrm{pl}, \mathrm{Rd}, \mathrm{f}}+\mathrm{N}_{\mathrm{fi}, \mathrm{pl}, \mathrm{Rd}, \mathrm{w}}+\mathrm{N}_{\mathrm{fi}, \mathrm{pl}, \mathrm{Rd}, \mathrm{c}}+\mathrm{N}_{\mathrm{fi}, \mathrm{pl}, \mathrm{Rd}, \mathrm{s}} \\
(\mathrm{EI})_{\mathrm{fi}, \mathrm{eff}, \mathrm{z}}=\phi_{\mathrm{f}, \theta}(\mathrm{EI})_{\mathrm{fi}, \mathrm{f}, \mathrm{z}}+\phi_{\mathrm{w}, \theta}(\mathrm{EI})_{\mathrm{fi}, \mathrm{w}, \mathrm{z}}+\phi_{\mathrm{c}, \theta}(\mathrm{EI})_{\mathrm{fi}, \mathrm{c}, \mathrm{z}}+\phi_{\mathrm{s}, \theta}(\mathrm{EI})_{\mathrm{fi}, \mathrm{s}, \mathrm{z}}
\end{gathered}
$$

In the current version model, the average flange temperature is obtained through equations using empirical factors, depending on the section factor. The yield stress and elastic modulus are affected by temperature, using reduction factors. The web geometry reduction is based on empirical factors. The yield stress is reduced using an indirect parameter, leaving the elastic modulus not affected by temperature. The concrete temperature is calculated using a table based on the section factor, for each class of fire resistance. Part of the concrete geometry is neglected using the same distance in the both principal directions and the mechanical proprieties are affected by temperature. The reinforcing bars have their mechanical properties affected by temperature, using the reduction factors for each size of concrete cover layer " $u$ ", obtained by the geometric average of " $u_{1}$ " and " $u_{2}$ ". The material safety factors $\gamma_{M, f i, a}, \gamma_{M, f i, c}$ and $\gamma_{M, f i, s}$ for the structural steel, concrete and reinforcing steel, respectively, are assumed equal to 1.

\begin{tabular}{|c|c|c|c|c|}
\hline \multicolumn{5}{|c|}{$\begin{array}{l}\text { Reduction coefficients for } \\
\text { bending stiffness }\end{array}$} \\
\hline Fire rating & $\phi_{\mathrm{f}, \theta}$ & $\phi_{\mathrm{w}, \theta}$ & $\phi_{\mathrm{c}, \theta}$ & $\phi_{\mathrm{s}, \theta}$ \\
\hline R30 & 1,0 & 1,0 & 0,8 & 1,0 \\
\hline R60 & 0,9 & 1,0 & 0,8 & 0,9 \\
\hline R90 & 0,8 & 1,0 & 0,8 & 0,8 \\
\hline R120 & 1,0 & 1,0 & 0,8 & 1,0 \\
\hline
\end{tabular}
The reduction coefficients of balanced summation are presented in Table 2.

Table 2. Reduction coefficients for balanced summation. 


\section{Buckling Resistance}

The annex $\mathrm{G}$ of Eurocode 4 part 1-2 [1] presents the simple calculation method to determine the buckling resistance of PEC. This method considers the effect of the fire over four components (flanges, web, concrete and reinforcing bars), when the PEC is submitted to a fire scenario from 4 sides. The stability of PEC requires the calculation of the critical load, the plastic resistance to axial compression and the effective flexural stiffness.

In order to consider the effect of a different fire scenario (fire from one side), seven components are required.

The elastic buckling load $\mathrm{N}_{\mathrm{fi}, \mathrm{cr}, \mathrm{z}}$ requires the calculation of the effective flexural stiffness $(\mathrm{EI})_{\mathrm{fi}, \mathrm{eff}, \mathrm{z}}$. The non-dimensional slenderness ratio $\lambda_{\theta}$, depends on the plastic resistance to axial compression under fire $\mathrm{N}_{\mathrm{fi}, \mathrm{pl}, \mathrm{Rd}}$ and should be calculated according to Eqs. 4 and 5. The buckling length of the column under fire conditions is represented by $\mathrm{L}_{\theta}$. In order to evaluate the buckling resistance, three buckling lengths were considered $\mathrm{L}_{\theta}=1 \mathrm{~L}, \mathrm{~L}_{\theta}=0,7 \mathrm{~L}$ and $\mathrm{L}_{\theta}=0,5 \mathrm{~L}$, assuming two different columns length $(3$ and 4 $\mathrm{m})$. According to the solution method, the buckling curve "C" of EN 1993-1-1 should be used to find the buckling resistance [12], using the reduction coefficient $\chi_{z}$.

$$
\begin{gathered}
\overline{\lambda_{\theta}}=\sqrt{\mathrm{N}_{\mathrm{fi}, \mathrm{pl}, \mathrm{Rd}} / \mathrm{N}_{\mathrm{fi}, \mathrm{cr}, \mathrm{z}}} \\
\mathrm{N}_{\mathrm{fi}, \mathrm{cr}, \mathrm{z}}=\pi^{2}(\mathrm{EI})_{\mathrm{fi}, \mathrm{eff}, \mathrm{z}} / \mathrm{L}_{\theta}^{2}
\end{gathered}
$$

The Fig. 2 presents the flowchart of the simplified calculation method used for the calculation of the buckling resistance of PEC.
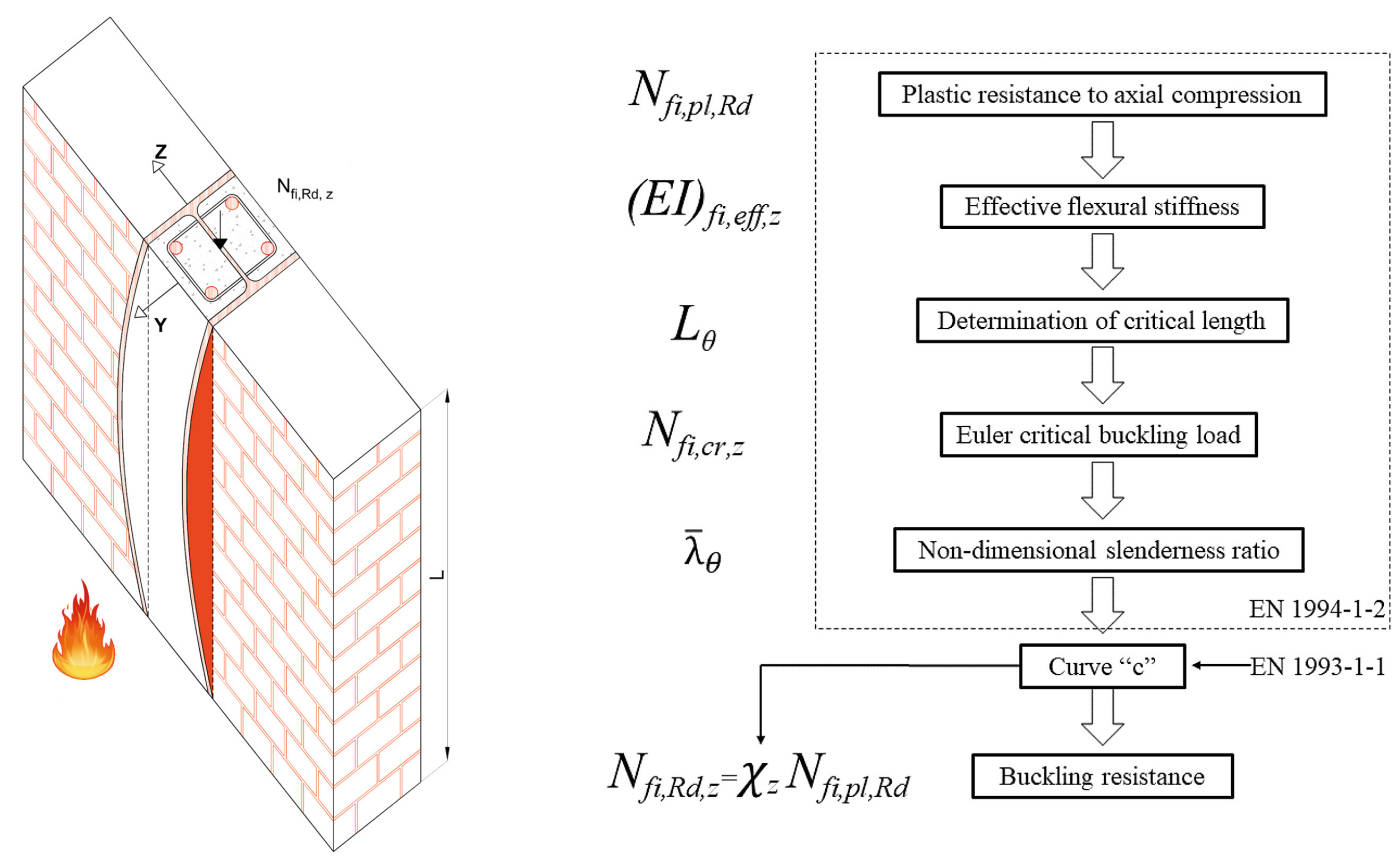

Fig. 2. Simplified calculation method. 


\section{Numerical Simulation}

The purpose of this work is to perform numerical simulations of composite steelconcrete columns in contact with clay walls under fire exposure from one side. The advanced calculation method was developed using the finite element method. This method requires the solution of Eq. 6 when submitted to the boundary conditions Eq. 7. The solution method is incremental and non-linear, which requires an iterative process. The post processing of the temperature field over the PEC is used to determine the average temperature of each component (exposed/unexposed flange, web, exposed/unexposed rebars, residual areas of the exposed and unexposed concrete) for different fire ratings.

$$
\begin{gathered}
\nabla\left(\lambda_{(\mathrm{T})} \cdot \nabla \mathrm{T}\right)=\rho_{(\mathrm{T})} \cdot \mathrm{C}_{\mathrm{p}(\mathrm{T})} \cdot \partial \mathrm{T} / \partial \mathrm{t} \rightarrow(\Omega) \\
\lambda_{(\mathrm{T})} \cdot \nabla \mathrm{T} \cdot \overrightarrow{\mathrm{n}}=\alpha_{\mathrm{c}}\left(\mathrm{T}_{\mathrm{g}}-\mathrm{T}\right)+\Phi \cdot \varepsilon_{\mathrm{m}} \cdot \varepsilon_{\mathrm{f}} \cdot \sigma \cdot\left(\mathrm{T}_{\mathrm{g}}^{4}-\mathrm{T}^{4}\right) \rightarrow(\partial \Omega)
\end{gathered}
$$

In these equations: $\lambda_{(T)}$ represents the thermal conductivity, $\rho_{(T)}$ defines the specific mass, $C p_{(T)}$ defines the specific heat, $\mathrm{T}$ represents the temperature of each material, $\mathrm{T}_{\mathrm{g}}$ defines the gas temperature of the fire compartment, $\alpha_{c}$ defines the convective coefficient, $\phi$ defines the view factor, $\varepsilon_{f}$ and $\varepsilon_{m}$ define the emissivity of fire and material respectively and $\sigma$ represents the Stephan-Boltzmann constant.

The finite element model, considers the incremental and iterative solution, using 2D finite elements PLANE55, which presents four nodes with a single degree of freedom (temperature at each node), using linear interpolating functions and full integration Gauss scheme. The mesh was well refined $(0.5 \mathrm{~mm}$ maximum size) to enable the calculation for the reduction of the concrete affected by the fire (exposed side) (see Fig. 3).

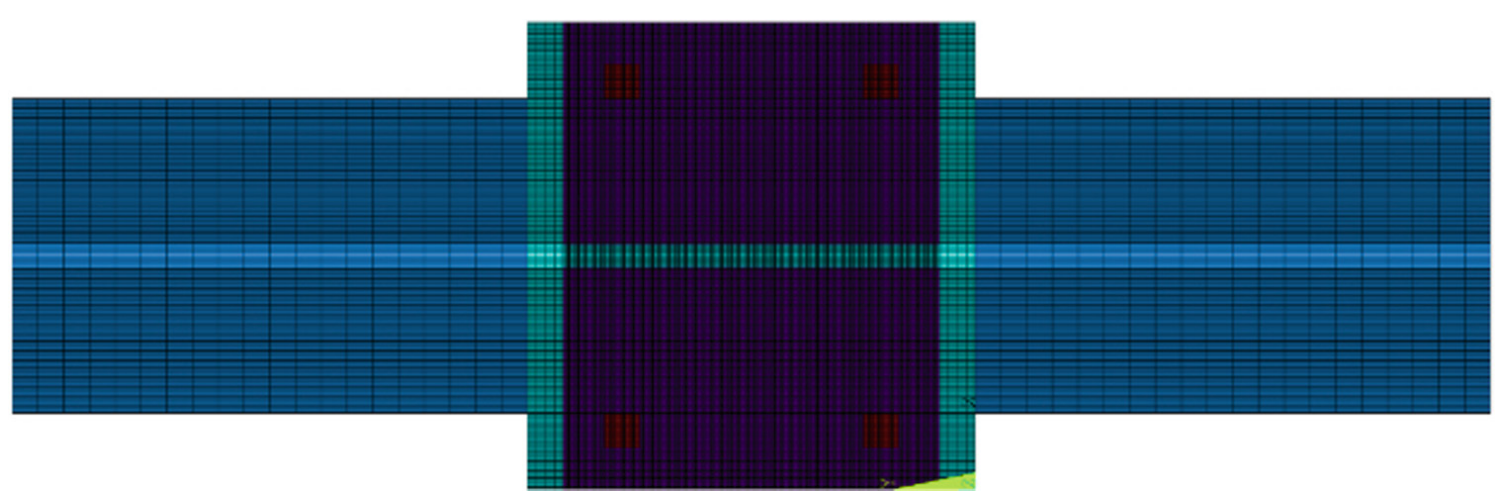

Fig. 3. Finite element mesh used for simulations.

Nonlinear thermal properties are used for steel, concrete and masonry, according to the Eurocodes EN1993-1-2 [13], EN1994-1-2 [1], EN1992-1-2 [14] and EN1996-1-2 [15]. The arithmetic average temperature of each component is based on the temperature of each node. The $500{ }^{\circ} \mathrm{C}$ isothermal is also used to define concrete layer to be neglected, $b_{c, f i, h}$, (see Fig. 4). 


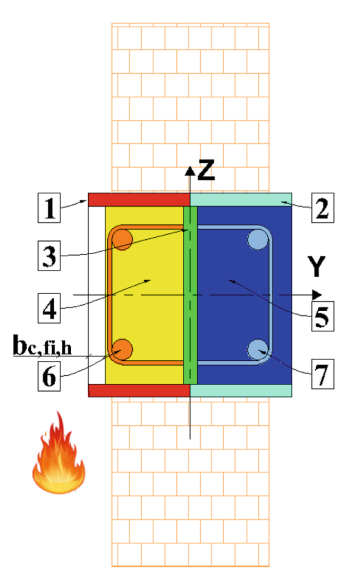

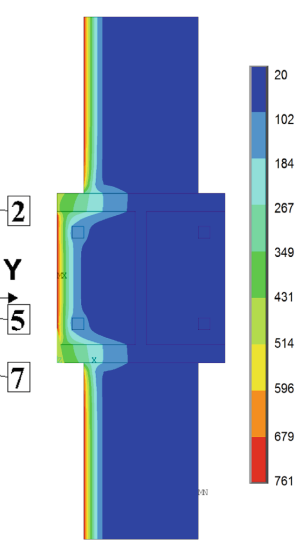

(a)

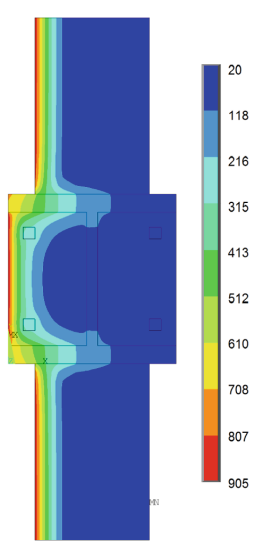

(b)

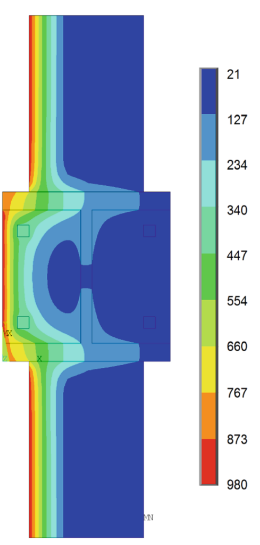

(c)

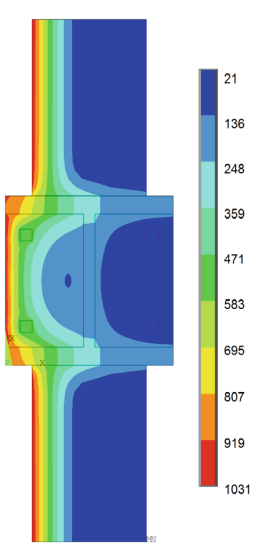

(d)

Fig. 4. Identification of the seven components based on the temperature distribution for (a) R30, (b) R60, (c) R90 and (d) R120.

The exposed side is submitted to standard fire conditions, using a convection coefficient of $25\left[\mathrm{~W} / \mathrm{m}^{2} \mathrm{~K}\right]$ and an emissivity of the fire equal to 1 . The unexposed side is submitted to a convective coefficient of $9\left[\mathrm{~W} / \mathrm{m}^{2} \mathrm{~K}\right]$ to include the radiation effect. An initial uniform temperature is applied to all the nodes $\left(20^{\circ} \mathrm{C}\right)$.

The nonlinear transient thermal analysis required an integration time step of $60 \mathrm{~s}$, which can decrease to $0.1 \mathrm{~s}$ and increase up to $60 \mathrm{~s}$. The criterion for convergence uses a tolerance value for the heat flow, smaller than $0.1 \%$ with a minimum reference value of $1 \times 10^{-6}$. The time history for the temperature evolution is depicted in Fig. 5, where one can see the high temperature gradient in direction perpendicular to the web, during $120 \mathrm{~min}$ of fire exposure.

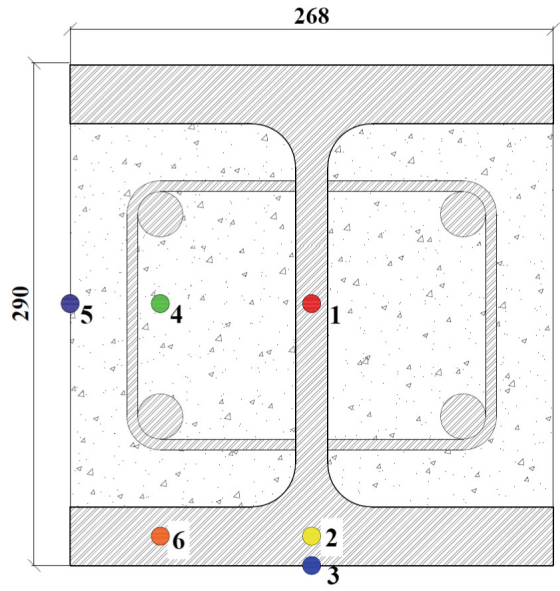

HD 260x172

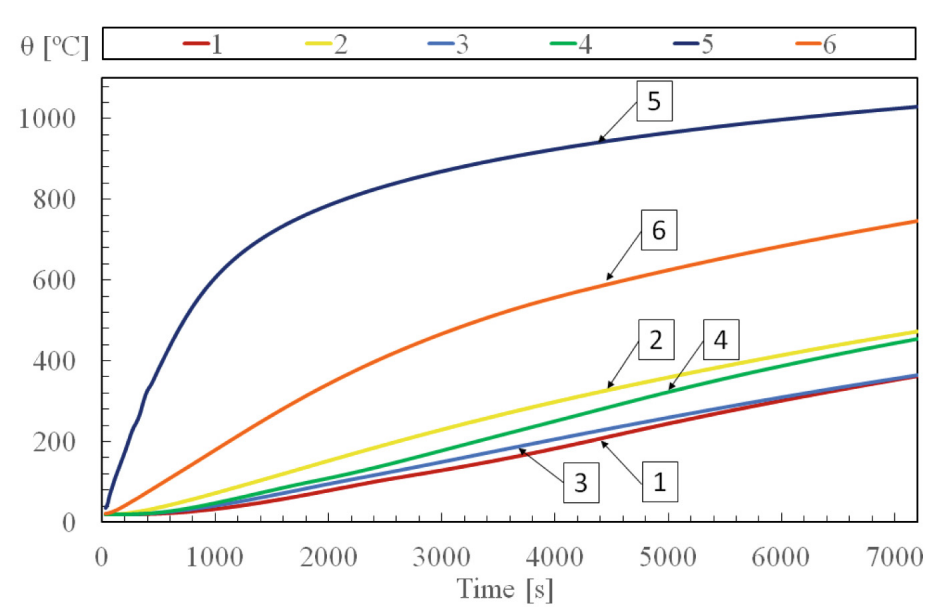

Fig. 5. Temperature evolution in cross section of profile HD $260 \times 172$. 


\section{Balanced Summation Model - New Proposal}

The new proposal for the balanced summation model requires new analytical formulae to take into consideration the effect of the fire in seven components. The flange, concrete and rebars are divided in two components (exposed to fire and not exposed to fire). The new proposal follows the same principle of the current Eurocode version EN1994-1-2 [1], but they are modified according to Eqs. 8 and 9. The reduction coefficients $\phi$, depend on the effect of thermal stresses and were kept almost equal to the current version of EN1994-1-2 [1], with exception to the coefficients $\phi_{f, \theta}$ and $\phi_{s, \theta}$ applied to R120, that should be modified to 0.8 .

$$
\begin{gathered}
\mathrm{N}_{\mathrm{fi}, \mathrm{pl}, \mathrm{Rd}}=\mathrm{N}_{\mathrm{fi}, \mathrm{pl}, \mathrm{Rd}, \mathrm{f}, \mathrm{e}}+\mathrm{N}_{\mathrm{fi}, \mathrm{pl}, \mathrm{Rd}, \mathrm{f}, \mathrm{ne}}+\mathrm{N}_{\mathrm{fi}, \mathrm{pl}, \mathrm{Rd}, \mathrm{w}}+\mathrm{N}_{\mathrm{fi}, \mathrm{pl}, \mathrm{Rd}, \mathrm{c}, \mathrm{e}} \\
+\mathrm{N}_{\mathrm{fi}, \mathrm{pl}, \mathrm{Rd}, \mathrm{c}, \mathrm{ne}}+\mathrm{N}_{\mathrm{fi}, \mathrm{pl}, \mathrm{Rd}, \mathrm{s}, \mathrm{e}}+\mathrm{N}_{\mathrm{fi}, \mathrm{pl}, \mathrm{Rd}, \mathrm{s}, \mathrm{ne}} \\
(\mathrm{EI})_{\mathrm{fi}, \mathrm{eff}, \mathrm{z}}=\phi_{\mathrm{f}, \theta}(\mathrm{EI})_{\mathrm{fi}, \mathrm{f}, \mathrm{e}, \mathrm{z}}+\phi_{\mathrm{f}, \theta}(\mathrm{EI})_{\mathrm{fi}, \mathrm{f}, \mathrm{en}, \mathrm{z}}+\phi_{\mathrm{w}, \theta}(\mathrm{EI})_{\mathrm{fi}, \mathrm{w}, \mathrm{z}}+\phi_{\mathrm{c}, \theta}(\mathrm{EI})_{\mathrm{fi}, \mathrm{c}, \mathrm{e}, \mathrm{z}} \\
+\phi_{\mathrm{c}, \theta}(\mathrm{EI})_{\mathrm{fi}, \mathrm{c}, \mathrm{ne}, \mathrm{z}}+\phi_{\mathrm{s}, \theta}(\mathrm{EI})_{\mathrm{fi}, \mathrm{s}, \mathrm{e}, \mathrm{z}}+\phi_{\mathrm{s}, \theta}(\mathrm{EI})_{\mathrm{fi}, \mathrm{s}, \mathrm{ne}, \mathrm{z}}
\end{gathered}
$$

\subsection{Flange Components}

The flange is divided into two components, half-flange exposed to fire and the halfflange not exposed to fire. New formulae are proposed for the calculation of the average temperature, based on some geometrical factors. Table 3 presents the improved equations for the average temperature of the components, with the respective parameters for each partially encased cross section type. The value $\theta_{\mathrm{fe}, \mathrm{t}}$ represents the average

\begin{tabular}{|c|c|c|c|c|c|c|c|c|c|}
\hline \multicolumn{10}{|c|}{$\theta_{\mathrm{fe}, \mathrm{t}}=\theta_{0, \mathrm{t}}+\mathrm{k}_{\mathrm{fe}, \mathrm{f}}\left(\mathrm{t}_{\mathrm{f}}\right)+\mathrm{k}_{\mathrm{t}, \mathrm{fe}}\left(\mathrm{A}_{\mathrm{m}} / \mathrm{V}\right)$} \\
\hline \multirow{2}{*}{$\begin{array}{l}\text { Standard fire } \\
\text { resistance }\end{array}$} & \multicolumn{3}{|l|}{ HEA } & \multicolumn{3}{|l|}{ HD } & \multicolumn{3}{|l|}{ UC } \\
\hline & $\begin{array}{l}\mathrm{k}_{\mathrm{f}, \mathrm{e}} \\
{\left[{ }^{\circ} \mathrm{C} / \mathrm{mm}\right]}\end{array}$ & $\begin{array}{l}\mathrm{k}_{\mathrm{t}, \mathrm{fe}} \\
{\left[\mathrm{m}^{\circ} \mathrm{C}\right]}\end{array}$ & $\begin{array}{l}\theta_{0, \mathrm{t}} \\
{\left[{ }^{\circ} \mathrm{C}\right]}\end{array}$ & $\begin{array}{l}\mathrm{k}_{\mathrm{f}, \mathrm{e}} \\
{\left[{ }^{\circ} \mathrm{C} / \mathrm{mm}\right]}\end{array}$ & \begin{tabular}{|l|}
$\mathrm{k}_{\mathrm{t}, \mathrm{fe}}$ \\
{$\left[\mathrm{m}^{\circ} \mathrm{C}\right]$}
\end{tabular} & \begin{tabular}{|l|l}
$\theta_{0, \mathrm{t}}$ & 1 \\
{$\left[{ }^{\circ} \mathrm{C}\right]$} & {[}
\end{tabular} & $\begin{array}{l}\mathrm{k}_{\mathrm{f}, \mathrm{e}} \\
{\left[{ }^{\circ} \mathrm{C} / \mathrm{mm}\right]}\end{array}$ & $\begin{array}{l}\mathrm{k}_{\mathrm{t}, \mathrm{fe}} \\
{\left[\mathrm{m}^{\circ} \mathrm{C}\right]}\end{array}$ & $\begin{array}{l}\theta_{0, \mathrm{t}} \\
{\left[{ }^{\circ} \mathrm{C}\right]}\end{array}$ \\
\hline R30 & 0.09 & 36 & 185 & -0.42 & 45.95 & $140-$ & -0.55 & 40.9 & 150 \\
\hline R60 & 1.48 & 45 & 295 & -0.40 & 59.6 & 254 & -0.53 & 54.5 & 262 \\
\hline R90 & 2.25 & 54 & 348 & -0.20 & 69.95 & 307 & -0.34 & 62.5 & 326 \\
\hline R120 & 3.15 & 58 & 389 & 0.01 & 74 & 344 & -0.20 & 67.0 & 375 \\
\hline \multicolumn{10}{|c|}{$\theta_{\text {fne, }}=\theta_{0, \mathrm{t}}+\mathrm{k}_{\mathrm{f}, \text { fne }}\left(\mathrm{t}_{\mathrm{f}}\right)+\mathrm{k}_{\mathrm{t}, \text { fne }}\left(\mathrm{A}_{\mathrm{m}} / \mathrm{V}\right)$} \\
\hline \multirow{2}{*}{$\begin{array}{l}\text { Standard fire } \\
\text { resistance }\end{array}$} & \multicolumn{3}{|c|}{ HEA } & \multicolumn{3}{|l|}{ HD } & \multicolumn{3}{|l|}{ UC } \\
\hline & $\begin{array}{l}\mathrm{k}_{\mathrm{f}, \text { fne }} \\
{\left[{ }^{\circ} \mathrm{C} / \mathrm{mm}\right]}\end{array}$ & $\begin{array}{l}\mathrm{k}_{\mathrm{t}, \text { fne }} \\
{\left[\mathrm{m}^{\circ} \mathrm{C}\right]}\end{array}$ & $\begin{array}{l}\theta_{0, \mathrm{t}} \\
{\left[{ }^{\circ} \mathrm{C}\right]} \\
\end{array}$ & $\begin{array}{l}\mathrm{k}_{\mathrm{f}, \mathrm{fne}} \\
{\left[{ }^{\circ} \mathrm{C} / \mathrm{mm}\right]}\end{array}$ & $\begin{array}{l}\mathrm{k}_{\mathrm{t}, \text { fne }} \\
{\left[\mathrm{m}^{\circ} \mathrm{C}\right]}\end{array}$ & $\begin{array}{l}\theta_{0, \mathrm{t}} \\
{\left[{ }^{\circ} \mathrm{C}\right]} \\
\end{array}$ & \begin{tabular}{|l|}
$\mathrm{k}_{\mathrm{f}, \text { fne }}$ \\
{$\left[{ }^{\circ} \mathrm{C} / \mathrm{mm}\right]$}
\end{tabular} & \begin{tabular}{|l|}
$\mathrm{k}_{\mathrm{t}, \text { fne }}$ \\
{$\left[\mathrm{m}^{\circ} \mathrm{C}\right]$} \\
\end{tabular} & $\begin{array}{l}\theta_{0, \mathrm{t}} \\
{\left[{ }^{\circ} \mathrm{C}\right]} \\
\end{array}$ \\
\hline $\mathrm{R} 30$ & 2.18 & 22 & -66.4 & 0.11 & 23.62 & -38 & 0.10 & 21.8 & -31 \\
\hline R60 & 5.19 & 41 & -139.0 & 0.30 & 46.8 & -63 & 0.30 & 42.0 & -45 \\
\hline R90 & 8.39 & 65 & -245.0 & 0.72 & 71.4 & -110 & \begin{tabular}{l|l}
0 & 0.79
\end{tabular} & 66.2 & -96 \\
\hline R120 & 10.20 & 85 & -305.0 & 0.92 & 93.8 & -144 & \begin{tabular}{l|l}
4 & 0.98
\end{tabular} & 83.8 & -110 \\
\hline
\end{tabular}
temperature on the exposed flange and $\theta_{\text {fne, }}$ represents the average temperature on the unexposed flange.

Table 3. New formulae and parameters for average flange temperature. 
The mechanical properties should be affected by the average temperature, using the reduction factors presented in EN1994-1-2 [1]. The calculation of the plastic resistance to axial compression and effective flexural stiffness for the flange component are represented in Eq. 10 and Eq. 11, and depend on the geometry and materials properties (yield stress: $f_{a y, f, e, t}, f_{a y, f, n e, t}$ and elastic modulus: $E_{a, f . e, t}, E_{a, f . n e, t}$ ).

$$
\begin{gathered}
\mathrm{N}_{\mathrm{fi}, \mathrm{pl}, \mathrm{Rd}, \mathrm{f}}=2\left[\frac{\left(\mathrm{b} / 2 \mathrm{t}_{\mathrm{f}} \mathrm{f}_{\mathrm{ay}, \mathrm{f}, \mathrm{e}, \mathrm{t}}\right)}{\gamma_{\mathrm{M}, \mathrm{fi}, \mathrm{a}}}\right]+2\left[\frac{\left(\mathrm{b} / 2 \mathrm{t}_{\mathrm{f}} \mathrm{f}_{\mathrm{ay}, \mathrm{f}, \mathrm{ne}, \mathrm{t}}\right)}{\gamma_{\mathrm{M}, \mathrm{fi}, \mathrm{a}}}\right] \\
(\mathrm{EI})_{\mathrm{fi}, \mathrm{f}, \mathrm{z}}=\left[2\left(\frac{\left(\mathrm{t}_{\mathrm{f}}(\mathrm{b} / 2)^{3}\right)}{12}+\frac{\mathrm{t}_{\mathrm{f}} \mathrm{b}^{3}}{32}\right) \mathrm{E}_{\mathrm{a}, \mathrm{f}, \mathrm{e}, \mathrm{t}}\right]+\left[2\left(\frac{\left(\mathrm{t}_{\mathrm{f}}(\mathrm{b} / 2)^{3}\right)}{12}+\frac{\mathrm{t}_{\mathrm{f}} \mathrm{b}^{3}}{32}\right) \mathrm{E}_{\mathrm{a}, \mathrm{f}, \mathrm{ne}, \mathrm{t}}\right]
\end{gathered}
$$

\subsection{Web Component}

The reduction of the web area is not considered in this proposal. Instead a new improvement is proposed, based on the average temperature of the entire web region. The new plastic resistance to axial compression and the effective flexural stiffness in this component use the temperature effect (average web temperature - $\theta_{\mathrm{w}, \mathrm{t}}$ on the material properties (affecting the yield stress and elastic modulus) for the new parameters (see Table 4).

\begin{tabular}{|c|c|c|c|c|c|c|c|c|c|}
\hline \multicolumn{10}{|c|}{$\theta_{\mathrm{w}, \mathrm{t}}=\theta_{0, \mathrm{w}}+\mathrm{k}_{\mathrm{w}, \mathrm{w}}\left(1 / \mathrm{t}_{\mathrm{w}}\right)+\mathrm{k}_{\mathrm{t}, \mathrm{w}}\left(\mathrm{A}_{\mathrm{m}} / \mathrm{V}\right)$} \\
\hline \multirow{2}{*}{$\begin{array}{l}\text { Standard fire } \\
\text { resistance }\end{array}$} & \multicolumn{3}{|c|}{ HEA } & \multicolumn{3}{|l|}{ HD } & \multicolumn{3}{|l|}{ UC } \\
\hline & $\begin{array}{l}\mathrm{k}_{\mathrm{w}, \mathrm{w}} \\
{\left[\mathrm{mm}^{\circ} \mathrm{C}\right]}\end{array}$ & $\begin{array}{l}\mathrm{k}_{\mathrm{t}, \mathrm{w}} \\
{\left[\mathrm{m}^{\circ} \mathrm{C}\right]}\end{array}$ & $\begin{array}{l}\theta_{0, \mathrm{w}} \\
{\left[{ }^{\circ} \mathrm{C}\right]}\end{array}$ & $\begin{array}{l}\mathrm{k}_{\mathrm{w}, \mathrm{w}} \\
{\left[\mathrm{mm}^{\circ} \mathrm{C}\right]}\end{array}$ & $\begin{array}{l}\mathrm{k}_{\mathrm{t}, \mathrm{w}} \\
{\left[\mathrm{m}^{\circ} \mathrm{C}\right]}\end{array}$ & $\begin{array}{l}\theta_{0, \mathrm{w}} \\
{\left[{ }^{\circ} \mathrm{C}\right]}\end{array}$ & $\begin{array}{l}\mathrm{k}_{\mathrm{w}, \mathrm{w}} \\
{\left[\mathrm{mm}^{\circ} \mathrm{C}\right]}\end{array}$ & $\begin{array}{l}\mathrm{k}_{\mathrm{t}, \mathrm{w}} \\
{\left[\mathrm{m}^{\circ} \mathrm{C}\right]}\end{array}$ & $\begin{array}{l}\theta_{0, \mathrm{w}} \\
{\left[{ }^{\circ} \mathrm{C}\right]}\end{array}$ \\
\hline R30 & 90.93 & 22.00 & -50 & -251.00 & 23.80 & 22.00 & -234.62 & 23.05 & 20.00 \\
\hline R60 & 344.12 & 36.00 & -75 & -694.57 & 49.00 & 30.00 & -630.00 & 50.00 & 35.00 \\
\hline R90 & 212.59 & 64.00 & 130. & 1220.32 & 79.00 & 45.00 & 1142.11 & 77.49 & 40.00 \\
\hline R120 & 578.77 & 73.00 & 145 & 1585.77 & 102.50 & 45.00 & 1500.00 & 103.00 & 45.00 \\
\hline
\end{tabular}

Table 4. New formulae and parameters for the web average temperature.

The plastic resistance to axial compression and effective flexural stiffness for the web, without any geometry reduction, should be calculated according to Eq. 12. These formulae depend on geometric parameters and materials properties (yield stress $f_{a y, w, t}$ and elastic modulus $\mathrm{E}_{\mathrm{a}, \mathrm{w}, \mathrm{t}}$ ).

$$
\begin{aligned}
& \mathrm{N}_{\mathrm{fi}, \mathrm{pl}, \mathrm{Rd}, \mathrm{w}}=\left[\mathrm{e}_{\mathrm{w}}\left(\mathrm{h}-2 \mathrm{t}_{\mathrm{f}}\right) \mathrm{f}_{\mathrm{ay}, \mathrm{w}, \mathrm{t}}\right] / \gamma_{\mathrm{M}, \mathrm{fi}, \mathrm{a}} \\
& (\mathrm{EI})_{\mathrm{fi}, \mathrm{w}, \mathrm{z}}=\left[\mathrm{E}_{\mathrm{a}, \mathrm{w}, \mathrm{t}}\left(\mathrm{h}-2 \mathrm{t}_{\mathrm{f}}\right) \mathrm{e}_{\mathrm{w}}^{3}\right] / 12
\end{aligned}
$$




\subsection{Concrete Components}

The concrete was considered divided into two components, concrete exposed to fire and concrete not exposed to fire. The average temperature of concrete components $\left(\theta_{\text {ce,t }}\right.$ and $\left.\theta_{\text {cne,t }}\right)$ requires a new formulae and new parameters according to Table 5. The $500{ }^{\circ} \mathrm{C}$ isothermal criterion was used to determine de maximum temperature and the region of concrete to be neglected. The concrete exposed to fire has an horizontal size reduction that should be calculated according to " $b_{c e, f i, h}$ ", see Table 6 . There is no reduction to the unexposed concrete for any fire rating.

Table 5. New formulae and parameters for average concrete temperature.

\begin{tabular}{|c|c|c|c|c|c|c|c|c|c|}
\hline \multicolumn{10}{|c|}{$\theta_{\mathrm{ce}, \mathrm{t}}=\theta_{0, \mathrm{t}}+\mathrm{k}_{\mathrm{ce}}\left(1 / \mathrm{t}_{\mathrm{w}}\right)+\mathrm{k}_{\mathrm{t}, \mathrm{ce}}\left(\mathrm{A}_{\mathrm{m}} / \mathrm{V}\right)$} \\
\hline \multirow{2}{*}{$\begin{array}{l}\text { Standard fire } \\
\text { resistance }\end{array}$} & \multicolumn{3}{|c|}{ HEA } & \multicolumn{3}{|l|}{ HD } & \multicolumn{3}{|l|}{ UC } \\
\hline & $\begin{array}{l}\mathrm{k}_{\mathrm{ce}} \\
{\left[{ }^{\circ} \mathrm{C} / \mathrm{mm}\right]}\end{array}$ & $\begin{array}{l}\mathrm{k}_{\mathrm{t}} \\
{\left[\mathrm{m}^{\circ} \mathrm{C}\right]}\end{array}$ & $\begin{array}{l}\theta_{0, \mathrm{t}} \\
{\left[{ }^{\circ} \mathrm{C}\right]}\end{array}$ & \begin{tabular}{|l|}
$\mathrm{kce}$ \\
{$\left[{ }^{\circ} \mathrm{C} / \mathrm{mm}\right]$}
\end{tabular} & $\begin{array}{l}\mathrm{k}_{\mathrm{t}} \\
{\left[\mathrm{m}^{\circ} \mathrm{C}\right]}\end{array}$ & $\begin{array}{l}\theta_{0, \mathrm{t}} \\
{\left[{ }^{\circ} \mathrm{C}\right]}\end{array}$ & $\begin{array}{l}\mathrm{k}_{\mathrm{ce}} \\
{\left[{ }^{\circ} \mathrm{C} / \mathrm{mm}\right]}\end{array}$ & $\begin{array}{l}\mathrm{k}_{\mathrm{t}} \\
{\left[\mathrm{m}^{\circ} \mathrm{C}\right]}\end{array}$ & $\begin{array}{l}\theta_{0, \mathrm{t}} \\
{\left[{ }^{\circ} \mathrm{C}\right]}\end{array}$ \\
\hline R30 & -131 & 30 & 24 & -37 & 28.0 & 33 & -172 & 26.5 & 50 \\
\hline R60 & 26 & 40 & 39 & -155 & 38.9 & 70 & -444 & 46.5 & 60 \\
\hline R90 & 86 & 50 & 35 & -449 & 58.9 & 75 & -785 & 68.9 & 50 \\
\hline R120 & 424 & 50 & 55 & -764 & 75.0 & 85 & -943 & 79.5 & 60 \\
\hline \multicolumn{10}{|c|}{$\theta_{\text {cne, }}=\theta_{0, \mathrm{t}}+\mathrm{k}_{\mathrm{f}, \mathrm{cne}}\left(1 / \mathrm{t}_{\mathrm{w}}\right)+\mathrm{k}_{\mathrm{t}, \mathrm{cne}}\left(\mathrm{A}_{\mathrm{m}} / \mathrm{V}\right)$} \\
\hline \multirow{2}{*}{$\begin{array}{l}\text { Standard fire } \\
\text { resistance }\end{array}$} & \multicolumn{3}{|c|}{ HEA } & \multicolumn{3}{|l|}{ HD } & \multicolumn{3}{|l|}{$\mathrm{UC}$} \\
\hline & $\begin{array}{l}\mathrm{k}_{\mathrm{ce}} \\
{\left[{ }^{\circ} \mathrm{C} / \mathrm{mm}\right]}\end{array}$ & $\begin{array}{l}\mathrm{k}_{\mathrm{t}} \\
{\left[\mathrm{m}^{\circ} \mathrm{C}\right]}\end{array}$ & $\theta_{0, \mathrm{t}}\left[{ }^{\circ} \mathrm{C}\right]$ & $\begin{array}{l}\text { kce } \\
{\left[{ }^{\circ} \mathrm{C} / \mathrm{mm}\right]}\end{array}$ & $\begin{array}{l}\mathrm{k}_{\mathrm{t}} \\
{\left[\mathrm{m}^{\circ} \mathrm{C}\right]}\end{array}$ & $\begin{array}{l}\theta_{0, \mathrm{t}} \\
{\left[{ }^{\circ} \mathrm{C}\right]}\end{array}$ & $\begin{array}{l}\mathrm{k}_{\mathrm{ce}} \\
{\left[{ }^{\circ} \mathrm{C} / \mathrm{mm}\right]}\end{array}$ & $\begin{array}{l}\mathrm{k}_{\mathrm{t}} \\
{\left[\mathrm{m}^{\circ} \mathrm{C}\right]}\end{array}$ & $\begin{array}{l}\theta_{0, \mathrm{t}} \\
{\left[{ }^{\circ} \mathrm{C}\right]}\end{array}$ \\
\hline $\mathrm{R} 30$ & -32 & 10.2 & -11.00 & -70 & 10.0 & -1 & -100 & 10.50 & -3.27 \\
\hline R60 & 79 & 22.7 & -48.00 & -272 & 27.6 & -29 & -348 & 27.80 & -29.00 \\
\hline R90 & 76 & 39.0 & -84.75 & -535 & 47.0 & -49 & -654 & 48.00 & -51.50 \\
\hline R120 & 75 & 53.9 & -118.00 & -683 & 56.9 & -35 & -888 & 54.80 & -17.00 \\
\hline
\end{tabular}

Table 6. New formulae and parameters for horizontal reduction of concrete exposed to fire.

\begin{tabular}{|c|c|c|c|c|c|c|c|c|c|}
\hline \multicolumn{10}{|c|}{$b_{c e, f i, h}=b_{0, c h}+k_{w, c h}\left(1 / t_{w}\right)+k_{t, c h}\left(A_{m} / V\right)$, if $\theta_{c, t}=500{ }^{\circ} \mathrm{C}$, then $b_{c, f i, h}=\left(b-t_{w}\right) / 2$} \\
\hline \multirow{2}{*}{$\begin{array}{l}\text { Standard fire } \\
\text { resistance }\end{array}$} & \multicolumn{3}{|l|}{ HEA } & \multicolumn{3}{|l|}{ HD } & \multicolumn{3}{|l|}{ UC } \\
\hline & $\begin{array}{l}\mathrm{b}_{0, \mathrm{ch}} \\
{[\mathrm{mm}]}\end{array}$ & $\begin{array}{l}\mathrm{k}_{\mathrm{t}, \mathrm{ch}} \\
{\left[\mathrm{m}^{2 \circ} \mathrm{C}\right]}\end{array}$ & $\begin{array}{l}\mathrm{k}_{\mathrm{w}, \mathrm{ch}} \\
{\left[\mathrm{mm}^{\circ} \mathrm{C}\right]}\end{array}$ & $\begin{array}{l}\mathrm{b}_{0, \mathrm{ch}} \\
{[\mathrm{mm}]}\end{array}$ & $\begin{array}{l}\mathrm{k}_{\mathrm{tch}} \\
{\left[\mathrm{m}^{2 \circ} \mathrm{C}\right]}\end{array}$ & $\begin{array}{l}\mathrm{k}_{\mathrm{wch}} \\
{\left[\mathrm{mm}^{\circ} \mathrm{C}\right]}\end{array}$ & $\begin{array}{l}\mathrm{b}_{0, \mathrm{ch}} \\
{[\mathrm{mm}]}\end{array}$ & $\begin{array}{l}\mathrm{k}_{\mathrm{tch}} \\
{\left[\mathrm{m}^{2 \circ} \mathrm{C}\right]}\end{array}$ & $\begin{array}{l}\mathrm{k}_{\mathrm{wch}} \\
{\left[\mathrm{mm}^{\circ} \mathrm{C}\right]}\end{array}$ \\
\hline R30 & 11.68 & 0 & 0 & 11.68 & 0.000 & 0 & 11.68 & 0.000 & 0 \\
\hline R60 & 25.4 & 0.05 & 17 & 23.25 & 0.026 & -4 & 23.00 & 0.026 & 4.52 \\
\hline R90 & 28 & 0.34 & -12 & 31.00 & 0.180 & -12 & 31.00 & 0.23 & -21 \\
\hline R120 & 31 & 0.25 & 65 & 38.00 & 0.400 & -26 & 38.00 & 0.400 & -27 \\
\hline
\end{tabular}

The Eqs. 13 and 14 present the formulae for the calculation of the plastic resistance to axial compression and the calculation of the effective flexural stiffness, for both components (concrete exposed and the concrete not exposed). These formulae depend on geometry and on the concrete materials properties (compressive resistance at elevated temperature, $\mathrm{f}_{\mathrm{c}, \theta}$ and secant elastic modulus at elevated temperature, $\mathrm{E}_{\mathrm{c}, \mathrm{sec}, \theta}$ ). 
The number 0.86 is a calibration factor. $I_{s, e, z}$ represents the second order moment of area of the reinforcing bars related to the $\mathrm{z}$ central axis and $\mathrm{I}_{\mathrm{c}, \mathrm{e}, \mathrm{z}}, \mathrm{I}_{\mathrm{c}, \mathrm{ne}, \mathrm{z}}$ represent the second order moment of the concrete area related to the $\mathrm{z}$ central axis, for the exposed and unexposed side, respectively.

$$
\begin{array}{r}
\mathrm{N}_{\mathrm{fi}, \mathrm{pl}, \mathrm{Rd}, \mathrm{c}}=\left[\frac{0,86\left\{\left(\left(\mathrm{~h}-2 \mathrm{t}_{\mathrm{f}}\right)\left(\mathrm{b} / 2-\mathrm{t}_{\mathrm{w}} / 2-\mathrm{b}_{\mathrm{ce}, \mathrm{fi}, \mathrm{h}}\right) / 12\right)-\mathrm{A}_{\mathrm{s}}\right\} \mathrm{f}_{\mathrm{c}, \theta}}{\gamma_{\mathrm{M}, \mathrm{fi}, \mathrm{c}}}\right] \\
+\left[\frac{0,86\left\{\left(\left(\mathrm{~h}-2 \mathrm{t}_{\mathrm{f}}\right)\left(\mathrm{b} / 2-\mathrm{t}_{\mathrm{w}} / 2\right) / 12\right)-\mathrm{A}_{\mathrm{s}}\right\} \mathrm{f}_{\mathrm{c}, \theta}}{\gamma_{\mathrm{M}, \mathrm{fi}, \mathrm{c}}}\right] \\
(\mathrm{EI})_{\mathrm{fi}, \mathrm{ce}, \mathrm{z}}=\left[\mathrm{E}_{\mathrm{c}, \mathrm{sec}, \theta}\left(\mathrm{I}_{\mathrm{c}, \mathrm{e}, \mathrm{z}}-\mathrm{I}_{\mathrm{s}, \mathrm{e}, \mathrm{z}}\right)\right]+\left[\mathrm{E}_{\mathrm{c}, \mathrm{sec}, \theta}\left(\mathrm{I}_{\mathrm{c}, \mathrm{ne}, \mathrm{z}}-\mathrm{I}_{\mathrm{s}, \mathrm{ne}, \mathrm{z}}\right)\right]
\end{array}
$$

\subsection{Rebar Components}

The average temperature of reinforcing rebars require a new approximation, using new parameters. The thermal behaviour of the reinforcing bars depends on its geometric position " $u$ " and on the section factor. The rebars are divided in two components, rebars exposed to fire and rebars not exposed to fire. The influence of geometric position " $u$ " is higher for the case of rebars exposed to fire. The new parameters are

\begin{tabular}{|c|c|c|c|c|c|c|}
\hline \multicolumn{7}{|c|}{$\theta_{\mathrm{s}, \mathrm{e}, \mathrm{t}}=\theta_{0, \mathrm{~s}, \mathrm{e}, \mathrm{t}}+\mathrm{k}_{\mathrm{t}, \mathrm{s}, \mathrm{e}}\left(\mathrm{A}_{\mathrm{m}} / \mathrm{V}\right)+\mathrm{k}_{\mathrm{u}, \mathrm{s}, \mathrm{e}}(\mathrm{u})$} \\
\hline \multirow[t]{2}{*}{ Standard fire resistance } & \multicolumn{3}{|c|}{ HEA } & \multicolumn{3}{|l|}{$\mathrm{HD} / \mathrm{UC}$} \\
\hline & $\theta_{0 \mathrm{~s}, \mathrm{e}, \mathrm{t}}\left[{ }^{\circ} \mathrm{C}\right]$ & $\mathrm{k}_{\mathrm{t}, \mathrm{s}, \mathrm{e}}\left[\mathrm{m}^{\circ} \mathrm{C}\right]$ & $\mathrm{k}_{\mathrm{u}, \mathrm{s}, \mathrm{e}}\left[\mathrm{m}^{\circ} \mathrm{C}\right]$ & $\theta_{0 \mathrm{~s}, \mathrm{e}, \mathrm{t}}\left[{ }^{\circ} \mathrm{C}\right]$ & $\mathrm{k}_{\mathrm{t}, \mathrm{s}, \mathrm{e}}\left[\mathrm{m}^{\circ} \mathrm{C}\right]$ & $\mathrm{k}_{\mathrm{u}, \mathrm{s}, \mathrm{e}}\left[\mathrm{m}^{\circ} \mathrm{C}\right]$ \\
\hline R30 & 310 & 0,4 & $-2,992$ & 140 & 6 & 0 \\
\hline R60 & 640 & 5,7 & $-6,719$ & 245 & 20 & 0 \\
\hline R90 & 765 & 11 & $-7,400$ & 360 & 22 & 0 \\
\hline R120 & 840 & 16 & $-7,600$ & 420 & 26 & 0 \\
\hline \multicolumn{7}{|c|}{$\theta_{\mathrm{s}, \mathrm{ne}, \mathrm{t}}=\theta_{0, \mathrm{~s}, \mathrm{ne}, \mathrm{t}}+\mathrm{k}_{\mathrm{t}, \mathrm{s}, \mathrm{ne}}\left(\mathrm{A}_{\mathrm{m}} / \mathrm{V}\right)+\mathrm{k}_{\mathrm{u}, \mathrm{s}, \mathrm{ne}}(\mathrm{u})$} \\
\hline \multirow[t]{2}{*}{ Standard fire resistance } & \multicolumn{3}{|c|}{ HEA } & \multicolumn{3}{|l|}{$\mathrm{HD} / \mathrm{UC}$} \\
\hline & $\theta_{0 \mathrm{~s}, \mathrm{e}, \mathrm{t}}\left[{ }^{\circ} \mathrm{C}\right]$ & $\mathrm{k}_{\mathrm{t}, \mathrm{s}, \mathrm{e}}\left[\mathrm{m}^{\circ} \mathrm{C}\right]$ & $\mathrm{k}_{\mathrm{u}, \mathrm{s}, \mathrm{e}}\left[\mathrm{m}^{\circ} \mathrm{C}\right]$ & $\theta_{0 \mathrm{~s}, \mathrm{e}, \mathrm{t}}\left[{ }^{\circ} \mathrm{C}\right]$ & $\mathrm{k}_{\mathrm{t}, \mathrm{s}, \mathrm{e}}\left[\mathrm{m}^{\circ} \mathrm{C}\right]$ & $\mathrm{k}_{\mathrm{u}, \mathrm{s}, \mathrm{e}}\left[\mathrm{m}^{\circ} \mathrm{C}\right]$ \\
\hline R30 & 20 & 3,5 & $-0,158$ & 10 & 4 & 0 \\
\hline R60 & 35 & 12,0 & $-0,61$ & -10 & 16 & 0 \\
\hline R90 & 45 & 17,5 & $-0,60$ & -9 & 25 & 0 \\
\hline R120 & -30 & 30,0 & 0,50 & 6 & 33 & 0 \\
\hline
\end{tabular}
present in Table 7.

Table 7. New formulae and parameters for the average temperature of exposed rebars. 
The Eqs. 15 and 16 are used for the calculation of the plastic resistance to axial compression and the calculation of the effective flexural stiffness for these components. The reduction of the mechanical properties (elastic modulus $E_{s}$ and yield stress $f_{s, y}$ ) is introduced by the average temperature of rebars, using the reduction factors $\left(\mathrm{K}_{\mathrm{s},-, \mathrm{E}, \theta}\right.$ and $\mathrm{K}_{\mathrm{sy}, \theta}$ ) also presented in EN1994-1-2 [1].

$$
\begin{aligned}
& \mathrm{N}_{\mathrm{fi}, \mathrm{pl}, \mathrm{Rd}, \mathrm{s}}=\left[\frac{\mathrm{A}_{\mathrm{s}, \mathrm{e}} \mathrm{k}_{\mathrm{sy}, \theta} \mathrm{f}_{\mathrm{s}, \mathrm{y}}}{\gamma_{\mathrm{M}, \mathrm{fi}, \mathrm{s}}}\right]+\left[\frac{\mathrm{A}_{\mathrm{s}, \mathrm{ne}} \mathrm{k}_{\mathrm{sy}, \theta} \mathrm{f}_{\mathrm{s}, \mathrm{y}}}{\gamma_{\mathrm{M}, \mathrm{fi}, \mathrm{s}}}\right] \\
& (\mathrm{EI})_{\mathrm{fi}, \mathrm{s}, \mathrm{z}}=\left[\mathrm{k}_{\mathrm{s}, \mathrm{e}, \mathrm{E}, \theta} \mathrm{E}_{\mathrm{s}} \mathrm{I}_{\mathrm{s}, \mathrm{e}, \mathrm{z}}\right]+\left[\mathrm{k}_{\mathrm{s}, \mathrm{ne}, \mathrm{E}, \theta} \mathrm{E}_{\mathrm{s}} \mathrm{I}_{\mathrm{s}, \mathrm{ne}, \mathrm{z}}\right]
\end{aligned}
$$

\section{Results}

New simple formulae are presented, based on the average temperature of each component and based on the residual area of the concrete for different fire ratings (R30, R60, R90 and R120). The comparison of the results is presented in Fig. 6, using the results of the finite element simulation and the results of the new formulae. All the results determined by the new proposal are in the safe side, when the comparison is made with the numerical results.

The plastic resistance to axial compression decreases with time, being the highest reduction verified to $\mathrm{R} 90$ and $\mathrm{R} 120$. No big reduction is expected to R30. The effective flexural stiffness also decreases with time, being in some cases almost $40 \%$ of the effective flexural stiffness at room temperature after 120 min of fire exposure.

The resistance to axial compression and effective flexural stiffness are used for the calculation of columns buckling resistance. The results are calculated through curve "c" of EN 1993-1-1 [12], based on the prescription of the current version of EN 1994-1-2 [1], using the new proposal, for 30, 60, 90 and $60 \mathrm{~min}$ of fire exposure, see Fig. 7. These calculations are presented for two different PEC lengths ( 3 and $4 \mathrm{~m}$ ) and three different boundary conditions (pinned-pinned, fixed-pinned, and fixed-fixed).

The non-dimensional slenderness depends on the buckling length, under fire conditions, of each partially encased column. The reduction coefficient for the buckling resistance is defined by the curve $\mathrm{c}$ of the EN1993-1-1 [12]. The columns with $4 \mathrm{~m}$ length present higher non-dimensional slenderness. For that reason, the buckling resistance is smaller. The reduction of the buckling resistance is smaller for the fixedfixed boundary condition, in comparison to the other boundary conditions. A few columns with $3 \mathrm{~m}$ length, after $30 \mathrm{~min}$ of fire exposure, are not susceptible to prone into buckling. 


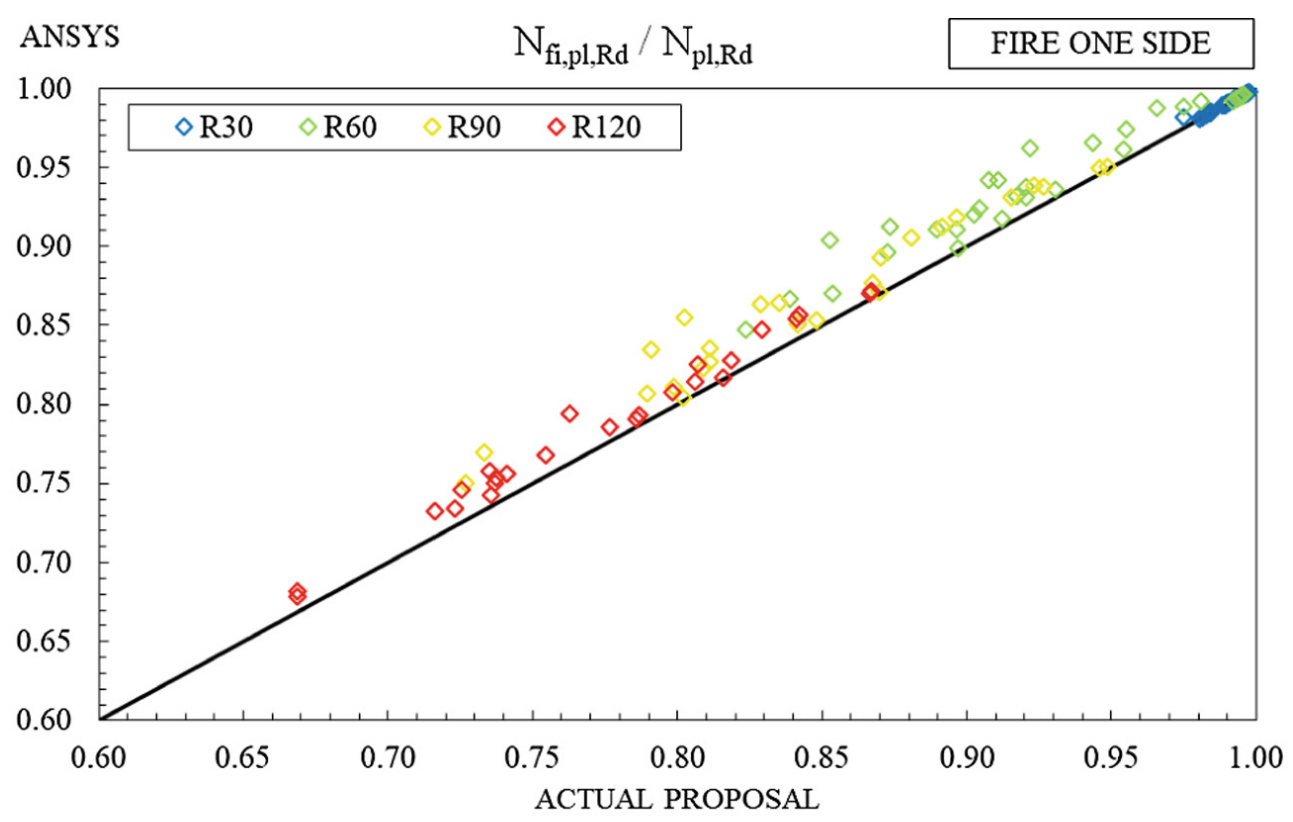

(a)

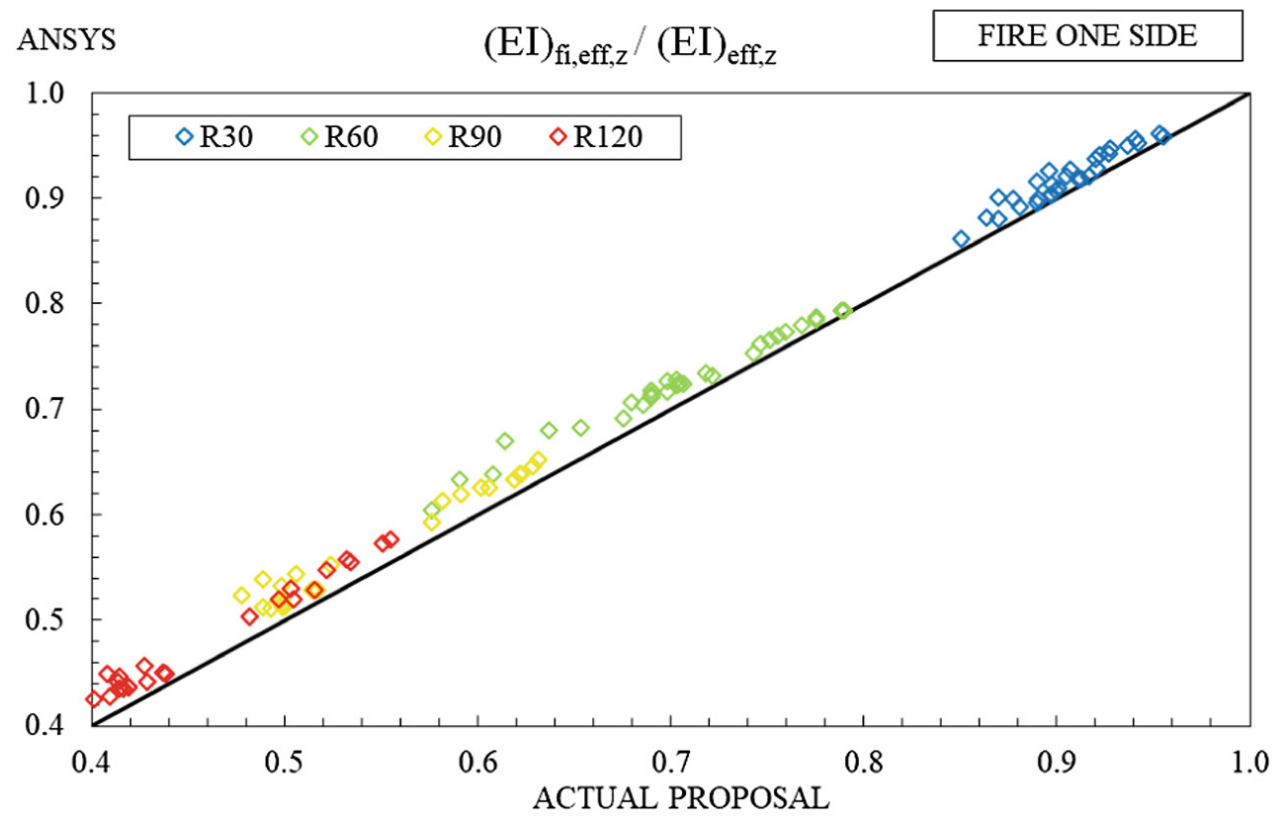

(b)

Fig. 6. Comparison results between the numerical simulation and improved formulae for the calculations of the resistance to axial compression (a) and effective flexural stiffness around the weak axis (b). 


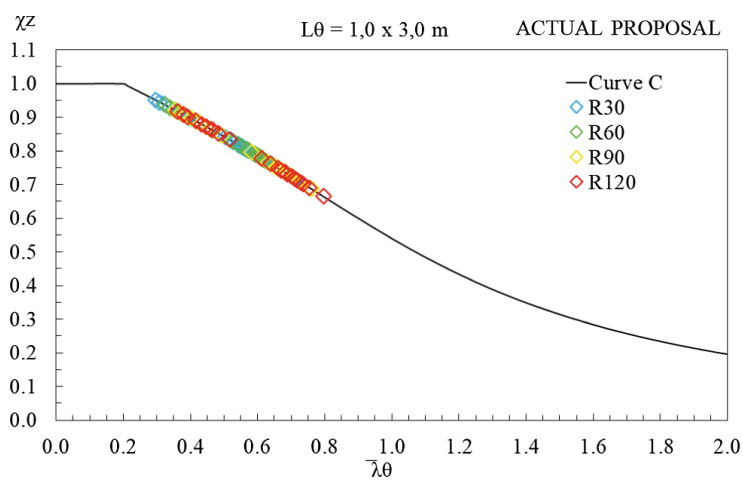

(a)

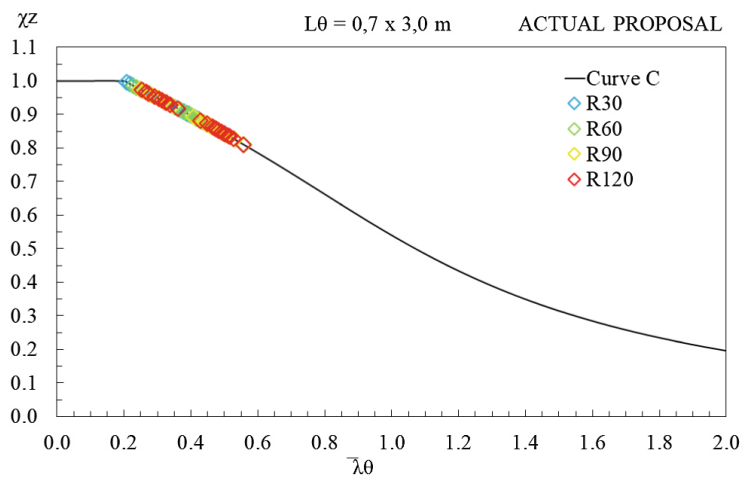

(b)

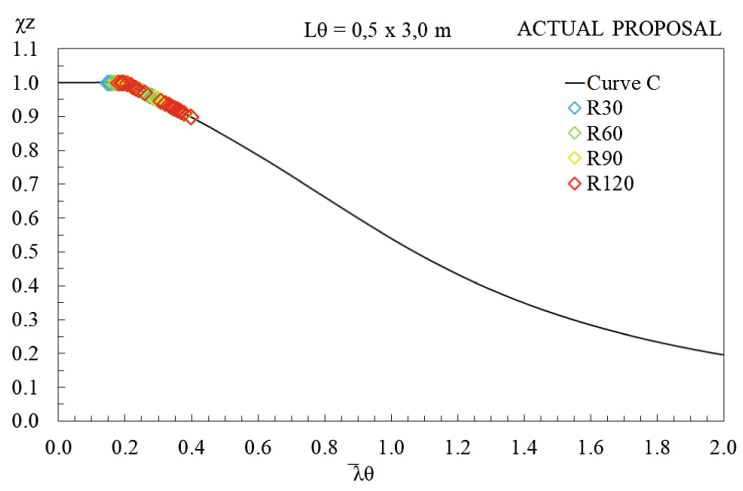

(c)

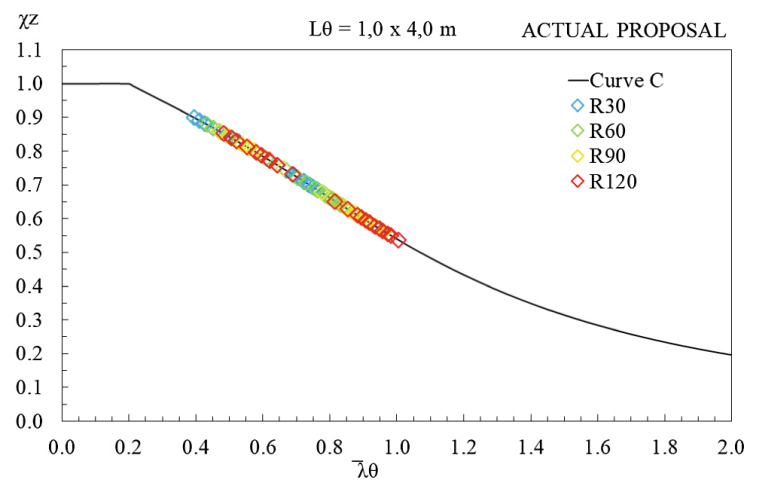

(d)

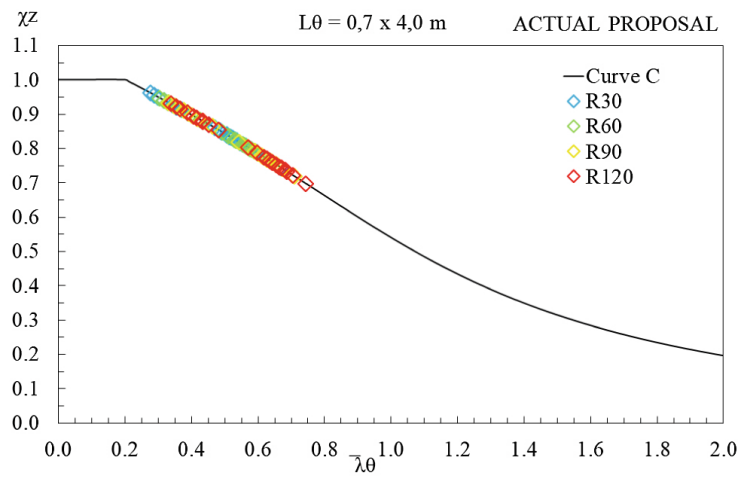

(e)

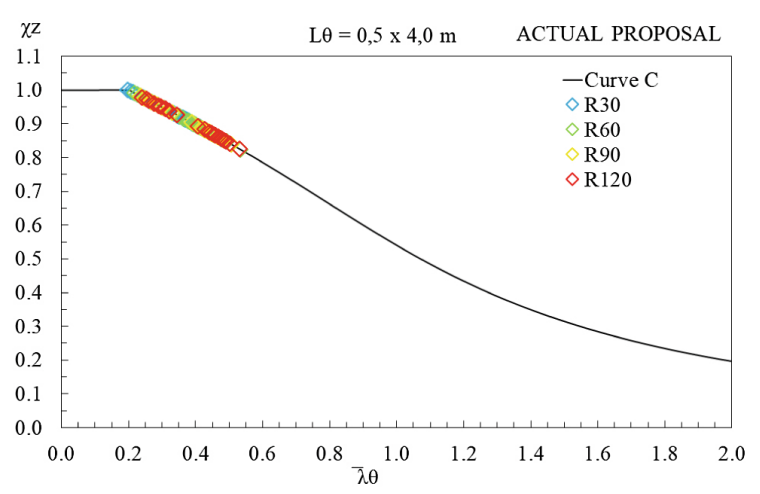

(f)

Fig. 7. Buckling curve for the lengths $L=3 \mathrm{~m}(\mathrm{a}, \mathrm{b}, \mathrm{c})$ and $\mathrm{L}=4 \mathrm{~m}(\mathrm{~d}, \mathrm{e}, \mathrm{f})$ for the three buckling lengths, for scenario fire one side, according to the Actual Proposal.

\section{Conclusion}

The simplified calculation method, proposed in annex G of EN1994-1-2 [1], does not provide any formulae for the fire design of PEC embedded in walls. The new proposal, presented herein, consider the PEC embedded in wall for the specific fire scenario (fire from one side). The wall partially protects the composite cross section from the fire effect, avoiding the reduction of the concrete region in the direction of the web. This 
proposal only considers the reduction of concrete in the direction perpendicular to the web and only in the exposed side block.

The maximum reduction to the plastic resistance to axial compression, after $120 \mathrm{~min}$ of fire exposure is $72 \%$, while the maximum reduction to the effective flexural stiffness is $40 \%$ for the same fire resistance.

The results obtained by numerical simulation for the calculation of the plastic resistance to axial compression and to the effective flexural stiffness are bigger than the results obtained from this new proposal, due to the fact that the approximation formulae are always providing higher average temperatures for each component (safety reason).

\section{References}

1. CEN- European Committee for Standardization, EN 1994-1-2: Design of composite steel and concrete structures. Part 1-2: General rules - Structural fire design, Brussels (2005)

2. ISO834-1, Fire-resistance tests - Elements of building construction - Part 1: General requirements, Switzerland, p. 25 (1999)

3. Cooke, G.M.E.: Thermal bowing and how it affects the design of fire separating construction. In: Proceedings of Interflam, London, vol. 88, pp. 230-236 (1988)

4. Garlock, M.E.M., Quiel, S.E.: Mechanics of wide-flanged steel sections that develop thermal gradients due to fire exposure. Int. J. Steel Struct. 7(3), 153-162 (2007)

5. Correia, A.M., Rodrigues, J.P., Silva, V.P.: A simplified calculation method for temperature evaluation of steel columns embedded in walls. Fire Mater. 35, 431-441 (2011). https://doi. org/10.1002/fam.1063

6. Dwaikat, M., Kodur, V., Quiel, S.E., Garlock, M.E.M.: Experimental behavior of steel, beam-columns subjected to fire-induced thermal gradients. J. Constr. Steel Res. 67, 30-38 (2011)

7. Agarwal, A., Choe, L., Varma, A.H.: Fire design of steel columns: effects of thermal gradients. J. Constr. Steel Res. 93, 107-118 (2014). https://doi.org/10.1016/j.jcsr.2013.10. 023. ISSN 0143-974X

8. Quiel, S.E., Garlock, M.E.M., Dwaikat, M.M.S., Kodur, V.K.R.: Predicting the demand and plastic capacity of axially loaded steel beam-columns with thermal gradients. Eng. Struct. 58, 49-62 (2014). https://doi.org/10.1016/j.engstruct.2013.10.005. ISSN 0141-0296

9. Correia, A.J.P.M., Rodrigues, J.P.C., Real, P.V.: Thermal bowing on steel columns embedded on walls under fire conditions. Fire Saf. J. 67, 53-69 (2014). https://doi.org/10. 1016/j.firesaf.2014.05.001

10. Ojeda, O.D., Maljaars, J., Abspoel, R.: Fire exposed steel columns with a thermal gradient over the cross-section. Thin-Walled Struct. 98, 103-110 (2016). https://doi.org/10.1016/j. tws.2015.02.009

11. Rocha, F.M., Rodrigues, J.P.C., Munaiar Neto, J.: Fire behavior of steel and partially encased composite columns embedded on walls. J. Constr. Steel Res. 149, 105-118 (2018). https://doi.org/10.1016/j.jcsr.2018.07.014

12. CEN- European Committee for Standardization, Eurocode 3: Design of steel structures - Part 1-1: General rules and rules for buildings, Brussels (2005) 
13. CEN- European Committee for Standardization, EN 1993-1-2: Design of steel structures Part 1-2: General rules - Structural fire design, Brussels (2005)

14. CEN- European Committee for Standardization, EN 1992-1-2: Design of concrete structures - Part 1-2: General rules - Structural fire design, Brussels (2004)

15. CEN - European Committee for Standardization, Eurocode 6: Design of masonry structures Part 1-2: General rules - Structural fire design, Brussels (2005) 